\title{
Association between Household Food Security and Anemia among Pregnant Women in Rural Area in Indonesia
}

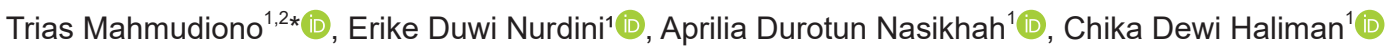 \\ ${ }^{1}$ Department of Nutrition, Faculty of Public Health, Universitas Airlangga, Surabaya, Indonesia; ${ }^{2}$ Center for Health and Nutrition \\ Education, Counseling and Empowerment, Airlangga, Surabaya, Indonesia
}

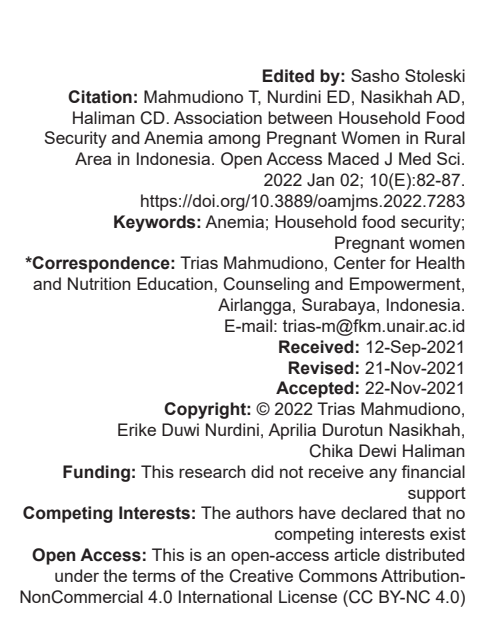

Introduction

Food is one of the main human needs in life competition. Fulfilling the needs of food is important for the country to the individual level, which is then called food security and has been regulated in Law Number 18 of 2012 concerning food [1]. Food security is also an important part of the country's development, because it has been listed in several points on the Sustainable Development Goals agreed by the United Nations Development Program in 2015 related to eradicating hunger [2]. Food security cannot be separated from the ability to access food.

Food access can affect the achievement of food security, especially in terms of economic or welfare, which includes income, employment opportunities, and food prices [3]. The economic capacity of rural populations is lower than in cities. Judging from BPS data, the number of poor people in East Java in March 2018 reached 4,332.59 thousand people, with the proportion of poor people in rural areas doubling more than urban areas [4].

The research location in Tuban District refers to BPS data, which shows the poverty rate reached
196,100 people or around $16.87 \%$ in March 2017 [5]. This figure occupies the fifth position in the category of districts, with the largest number of poor people in East Java during that period. In terms of poverty data, Tuban residents have the potential to experience the tendency of limited access to food, especially animal food groups. This is because animal food prices tend to be more expensive compared to other food ingredients [6]. The level of animal food consumption in rural areas is also considered being lower than in urban areas [7]. Animal food is a nutrient-rich food group, one of which is a good source of Fe [8]. Iron or Fe is closely related to the problem of anemia. Potential anemia problems increase during pregnancy. This can be seen through the increase in the proportion of anemia of pregnant women in Indonesia in 2013 by $37.1-48.9 \%$ in 2018 [9]. This pregnancy anemia problem is also still found in Bektiharjo Village, Semanding District.

Based on the background of the researcher, this research is to find out the relationship between household food security status and anemia in pregnant women in Bektiharjo Village, Semanding District, Tuban Regency. 


\section{Materials and Methods}

This research was an observational study with a cross-sectional design [10]. The target population in this study was pregnant women who lived in Bektiharjo Village in Semanding District, Tuban Regency. The sample was selected based on the data from the Semanding Health Center until April 2019. The total sample analyzed in this study was 50 pregnant women were living in the village of Bektiharjo.

Primary data were obtained from interviews using a questionnaire, while secondary data were obtained from the Semanding Health Center. Determination of household food security status using the United States Household Food Security Survey Module (US-HFSSM) questionnaire as an instrument (Figure 1), while anemia status was determined using a digital measuring instrument (Easy Touch $\mathrm{GCHb}$ ). The analysis uses the Pearson correlation statistic test to determine the significance of the relationship between the two variables with a value of $\alpha=0.05$. This study has been declared ethical passes with number 421/ HRECC.FODM/VII/2019 from the ethics committee of the Faculty of Dentistry, Universitas Airlangga, and carried out between 10 August until 8 September 2019.

\section{Results}

\section{Characteristics of respondents}

Characteristics of respondents could be seen through Table 1 which contains several variables namely the age of pregnant women, gestational age, household income, hemoglobin levels, and household food security status. Based on age, it was known that the majority of respondents were at healthy reproductive age $(76 \%)$, the other group age was $>35$ years old $(18 \%)$, and the rest were $\leq 19$ years old $(8 \%)$. Gestational age was dominated by trimester three pregnancies (44\%), and the rest were by trimester $1(20 \%)$ and 2 (36\%).

Based on the history of formal education they have, the highest percentage was in pregnant women graduating from junior high school (48\%) and primary school (28\%). Only $24 \%$ of them graduated from high school and no respondent graduated from university. Meanwhile, in terms of total household income was categorized into five quintiles, most respondents $(40 \%)$ were in quintile two, namely the income category between IDR $1,680,000$ to IDR $2,160,000$. Few respondents were having a household income of more than IDR 3,000,000, that is, Q4 (14\%) and Q5 (2\%).
Table 1: Distribution of characteristics of pregnant women in Bektiharjo village in 2019

\begin{tabular}{|c|c|c|}
\hline Variable & $\mathrm{n}$ & $\%$ \\
\hline \multicolumn{3}{|l|}{ Age of respondents } \\
\hline$\leq 19$ years old & 3 & 6 \\
\hline $20-35$ years old & 38 & 76 \\
\hline$>35$ years old & 9 & 18 \\
\hline \multicolumn{3}{|l|}{ Age of pregnancy } \\
\hline Trimester 1 & 10 & 20 \\
\hline Trimester 2 & 18 & 36 \\
\hline Trimester 3 & 22 & 44 \\
\hline \multicolumn{3}{|l|}{ Household income } \\
\hline Quintile 1 & 12 & 24 \\
\hline Quintile 2 & 20 & 40 \\
\hline Quintile 3 & 10 & 20 \\
\hline Quintile 4 & 7 & 14 \\
\hline Quintile 5 & 1 & 2 \\
\hline \multicolumn{3}{|l|}{ Educational background } \\
\hline Primary school & 14 & 28 \\
\hline Junior high school & 24 & 48 \\
\hline Senior high school & 12 & 24 \\
\hline \multicolumn{3}{|l|}{ Hemoglobin levels } \\
\hline$<11 \mathrm{~g} / \mathrm{dl}$ & 16 & 32 \\
\hline$\geq 11 \mathrm{~g} / \mathrm{dl}$ & 34 & 68 \\
\hline \multicolumn{3}{|l|}{ Household food security status } \\
\hline Food secure & 27 & 54 \\
\hline Food insecure without hunger & 19 & 38 \\
\hline Food insecure with moderate hunger & 4 & 8 \\
\hline Food insecure with severe hunger & 0 & 0 \\
\hline
\end{tabular}

\section{Hemoglobin levels and household food} security status

The digital measuring instrument tested respondents' hemoglobin levels. Averagely, respondents have $\geq 11 \mathrm{~g} / \mathrm{dl}$ of hemoglobin level $(68 \%)$. However, pregnant women with anemia were still found (32\%). According to the result of the US-HFSSM Questionnaire, four categories have been defined to simplify the food security scale into a small set of categories, each one representing a meaningful range of severity: food secure, food insecure without hunger, food insecure with moderate hunger, and food insecure with severe hunger [11]. Most of the respondents were classified into food-secure households (54\%). The others were counted as food insecure households, either without starvation $(38 \%)$ or with moderate hunger ( $8 \%$ ). Despite $46 \%$ of them still in food-insecure condition, there was no household with severe hunger founded.

As seen in Table 2, it was known that of the total pregnant women who have anemia, 13 of them were in food insecure conditions. Most pregnant women who did not have anemia were coming from food-secured households. This showed that there was a tendency that pregnant women who were food-insecure had a higher risk for anemia compared to those in the foodsecure household. The Pearson product-moment test showed $p=0.019(<0.005)$ with a large correlation of -0.331 .

Table 2: Cross tabulation of household food security status with anemia status of pregnant women in Bektiharjo village in 2019

\begin{tabular}{|c|c|c|c|c|c|c|c|}
\hline \multirow[t]{3}{*}{ Household food security status } & \multicolumn{4}{|c|}{$\begin{array}{l}\text { Anemia status of } \\
\text { pregnant women }\end{array}$} & \multicolumn{2}{|c|}{ Total } & \multirow[t]{3}{*}{$\mathrm{p}$-value } \\
\hline & \multicolumn{2}{|c|}{ Anemia } & \multicolumn{2}{|c|}{ No anemia } & \multirow[t]{2}{*}{$\mathrm{n}$} & \multirow[t]{2}{*}{$\%$} & \\
\hline & $\mathrm{n}$ & $\%$ & $\mathrm{n}$ & $\%$ & & & \\
\hline Food security & 3 & 11.1 & 24 & 88.9 & 27 & 100 & 0.019 \\
\hline Food insecurity without starvation & 10 & 52.6 & 9 & 47.4 & 19 & 100 & \\
\hline Food insecurity with moderate hunger & 3 & 75 & 1 & 25 & 4 & 100 & \\
\hline Food insecurity with severe hunger & 0 & 0 & 0 & 0 & 0 & 0 & \\
\hline
\end{tabular}


The results showed that most respondents were food secure. This was based on Table 1 which stated that more than half of the respondents have food security status (54\%). However, $46 \%$ of the households were living in some type of food security. There were no households that experienced food insecurity with severe hunger. The food security of a household can be influenced by several factors, especially food access, which is influenced by income. This was related to the proportion of expenditure for food from total income owned [12]. Most of the respondents were having relatively low income, with only a small portion having a household income between quintiles four and five. Household income was related to the ability to access food to meet nutritional needs [13]. Especially for certain foodstuffs that have a relatively high economic value, such as animal protein [14]. Apart from the economic aspect, daily consumption patterns can also be influenced by insight or knowledge [15].

\section{Discussion}

The education level of pregnant women can be used as an indicator to determine the acceptability of nutritional information that is possible to get during pregnancy [16]. Only a small proportion of respondents graduated from high school (24\%), while the rest were elementary and junior high school graduates. Therefore, income and education can be taken into consideration in choosing the type of food to consume. Food sources of both heme and non-heme iron were needed to meet the increased need for iron during pregnancy. Besides, foods that contain lots of Vitamin $\mathrm{C}$ were also good for pregnant women to consume, because they can be classified as enhancers of iron absorption [17]. Other types of food that need to be considered by pregnant women were foods or drinks that contain tannins such as tea and coffee because it acts as an iron inhibitor or inhibitor [18].

Animal-source foods contain good sources of nutrients and were needed by humans, including micronutrients such as iron (Fe) [8]. There was about $40 \%$ of heme iron derived from animal food, with good biological availability of around $23 \%$ [19], so that nutrients were more easily absorbed and used by the body. The content of iron in these foods was needed especially for pregnant women because during pregnancy the need for iron has increased. Iron was also mentioned as one of the important micronutrients in pregnancy which was listed in a special message of balanced nutrition [20]. This was related to the increase in red blood cell mass and plasma volume and preparation of iron loss during childbirth [7]. Therefore, pregnant women are included in the groups that have a high risk of anemia [21].

The anemia status data on respondents in this study were known through the results of measurements of hemoglobin levels in pregnant women. According to Table 1, 16 pregnant women (32\%) were found to be anemic. This showed that the majority of respondents did not experience anemia during pregnancy. This can be influenced by gestational age. Most respondents were in the $1^{\text {st }}$ and $2^{\text {nd }}$ trimester of pregnancy (56\%), which has a lower potential for anemia than in the $3^{\text {rd }}$ trimester of pregnancy [21].

These results indicated that there was a significant relationship between household food security status and anemia among pregnant women. The correlation between the two variables was inversely related, since the value was negative. This indicated that the lower the US-HFSSM score, the higher the hemoglobin level. This could be interpreted that the more food secure household was the less potential for pregnant women to experience anemia.

The results of this study have similarities with several previous studies. Several similar studies have also been conducted to determine the relationship of food security with anemia, especially in women of childbearing age. One study conducted on women of childbearing age in Mexico showed the results that women who were of medium and severe food insecurity had a $33 \%$ and $36 \%$ greater risk of anemia from iron deficiency compared to those who were food resistant [22]. Other research also states that a positive relationship was found between food insecure households and anemia in women of childbearing age (15-49 years) in Bangladesh [23]. The study said that women who experience food insecurity are 1.6 times more likely to suffer anemia than those who are food resistant. A similar study conducted in Brazil concluded that the likelihood of developing anemia in pregnant women was significantly higher especially in food insecure situations, without prenatal care or iron supplementation, and multiparous or women who had given birth more than once [24]. This can be explained by a study conducted in Malaysia that food insecure respondents consume less iron-rich foods such as meat, fish, poultry, and legumes compared to those who are food insecure [25]

There were several limitations in this study including study design and limited samples size. Furthermore, there are not enough parameters to show the effect of education, age, and income on anemic patients. However, this study also has its strength especially related to the process of collecting primary data which includes questionnaire interviews and hemoglobin tests on respondents conducted door-to-door so that the implementation was more focused and conducive.

\section{Conclusions}

Pregnant women with food-insecure household status are more at risk of experiencing anemia, especially 
iron-deficiency anemia. The better the household food security status, the lower the risk of anemia, especially iron deficiency anemia. Food sources of heme iron were good in animal source foods which were relatively more expensive than other types of food. Therefore, pregnant women should also be advised to consume non-heme iron source foods and food ingredients that can act as enhancers of iron absorption because they tend to be cheaper or affordable prices.

\section{Data Availability}

All the relevant data used to present the study are available; however, the corresponding author will supply the data on request.

\section{Acknowledgments}

The author is grateful for all the assistance given by the health center, Posyandu cadre, and respondents in Bektiharjo Village Semanding Sub-District Tuban District. Awards are also given to all teaching staff of the Nutrition Study Program of the Faculty of Public Health, Universitas Airlangga, for their support and guidance.

\section{References}

1. Undang-Undang Republik Indonesia Nomor 18 Tahun 2012 Tentang Pangan; 2012. https://doi.org/10.31219/osf.io/pmwny

2. Fan S, Brzeska J. Sustainable food security and nutrition: Demystifying conventional beliefs. Glob Food Sec. 2016;11(1):11-6. https://doi.org/10.1016/j.gfs.2016.03.005

3. Tajerin T, Sastrawidjaja S, Yusuf R. Welfare level and food security at poor fisher's household: Case studies in Marunda Baru village, DKI Jakarta and Tanjung Pasir Village, Banten. J Sosek. 2011;6(1):83-102. https://doi.org/10.15578/jsekp. v6i1.5757

4. BPS Jatim. Profil Kemiskinan di Jawa Timur Maret 2018. Berita Resmi Statistik; 2018. p. 1-8.

5. BPS Tuban. Profil Kemiskinan di Kabupaten Tuban Maret 2017 Persentase di Kabupaten. Berita Resmi Statistik; 2018. p. 1-7.

6. Susanti N, Endah WR. Analysis of household animal based food demand in West Java province. J Econ Dev Policy. 2014;3(1):42-63.

7. Fitri YP, Briawan D, Tanziha I, Madanijah S, Masyarakat DG, Manusia FE, et al. Adequacy and bioavailability of iron intake among pregnant women in tangerang. J MKMI. 2016;12(3):185-91

8. Furkon LA. Mengenal zat gizi. In: IImu Kesehatan Gizi; 2014.

\section{p. 1-53.}

9. Balitbangkes RI. Hasil Utama Riset Kesehatan Dasar 2018. Kementrian Kesehatan Republik Indonesia; 2018.

10. Ariani M, Suryana A, Suhartini SH, Saliem HP. Performance of animal food consumption based on region and income at household level. 2018;16(2):147-63.

11. Bickel G, Nord M, Price C, Hamilton W, Cook J. Guide to Measuring Household Food Security. Alexandria, VA, USA: US Department of Agriculture, Food and Nutrition Service; 2000. p. 75. Available from: http://www.fns.usda.gov/fsec/files/fsguide. pdf [Last accessed on 2021 Oct 01].

12. Purwaningsih Y. Food Security: Situation, Problems, Policies, and Community Empowerment. J Dev Econ. 2008;9(1):1-27. https://doi.org/10.23917/jep.v9i1.1028

13. Yudaningrum A. Analysis the Relation between Proportion of Expenditure and Food Consumption with Food Security of Farmer Household in Kulon Progo Regency, UNS-Skripsi; 2011. p. 1-79.

14. Suryanty M, Reswita R. Analisis konsumsi pangan berbasis protein hewani di kabupaten lebong: Pendekatan model aids (almost ideal demand system). J AGRISEP. 2016;15(1):101-10. https://doi.org/10.31186/jagrisep.15.1.101-110

15. Sukmaningtiyas $D$. Hubungan Antara Tingkat Pengetahuan dan Status Gizi Ibu Hamil Dengan Kejadian Anemia di Puskesmas Gatak Kabupaten Sukoharjo, Universitas Muhammadiyah Surakarta; 2015. https://doi.org/10.34310/sjkb.v3i1.48

16. Kusuma R, Khomsan A, Kustiyah L. Fish consumption in pregnant women and its relation to birth outcome. Indones Public Heal Media J. 2017;13(4):295.

17. Khaidir M. Iron Deficiency Anemia. J Masy Health. 2007;2(1):140-5.

18. Pratiwi R, Widari $D$. Relation of iron enhancer and inhibitor food consumption with anemia in pregnant women. Amerta Nutr. 2018;2(3):283.

19. Du S, Zhai F, Wang Y, Popkin BM. Current methods for estimating dietary iron bioavailability do not work in China. J Nutr. 2000;130(2):193-8.

20. Kementerian Kesehatan Republik Indonesia. Peraturan Menter Kesehatan Republik Indonesia Nomor 41 Tahun 2014 Tentang Pedoman Gizi Seimbang; 2014. p. 1-96.

21. Wati DW, Febry F, Rahmiwati A. Factors of Iron Deficiency On Pregnant Woman In Gandus Public Health Center Working Area In Palembang. J Public Health. 2016;7(1):42-7.

22. Fischer NC. Household Food Insecurity and Iron Deficiency Anemia in Mexican Women of Reproductive Age. United States: Yale University; 2014.

23. Ghose B, Tang S, Yaya S, Feng Z. Association between food insecurity and anemia among women of reproductive age. PeerJ. 2016;4:e1945. https://doi.org/10.7717/peerj.1945 PMid:27168968

24. Demétrio F, Teles-Santos C, Santos D. Food insecurity, prenatal care and other anemia determinants in pregnant women from the NISAMI Cohort, Brazil: Hierarchical model concept. Rev Bras Ginecol Obstet. 2017;39(8):384-96. https://doi. org/10.1055/s-0037-1604093 PMid:28666298

25. Sulaiman N, Shariff ZM, Jalil RA, Nasir M, Taib M, KandiahM et al. Validation of the Malaysian coping strategy instrument to measure household food insecurity in Kelantan, Malaysia. Food Nutr Bull. 2015;32(4):354-64. https://doi. org/10.1177/156482651103200407

PMid:22590969 


\section{Supplement Figure 1}

\section{K. HOUSEHOLD FOOD SECURITY STATUS}

US- HFSSM

The next questions are about the state of the food in your home in the past 12 months, i.e., since (MONTH) last year until now, whether you can afford to buy food easily or not. Which of the following statements best describes the food condition in your family in the past 12 months

[1] The quantity is sufficient, and the type of food is what we wanted [Skip 1a and 1b]

[2] The quantity is sufficient, but the type is not always what we want [Skip 1a; ask 1b]

[3] sometimes there are not enough [ask 1a; Skip 1b]

$1 \mathrm{a}$

[4] Often not enough [Ask 1a; Skip 1b]

[IF THE ANSWER TO QUESTION NO 1 II ${ }^{[3]}$ OR [4], ASK] whether it happened because of [READ ALL. PLEASE MARK APPROPRIATE RESPONDENT'S ANSWER]

$1=$ Yes $0=$ No

1. Don't have enough money to buy food

$66=T R$

2. Not having enough time to buy or cook food

3. It is too difficult to reach the grocery/market

4. On a diet

5. The stove is broken

6 Unable to cook or eat due to health problems

$\mathrm{K} 1 \mathrm{a} 1[]$

$\mathrm{K} 1 \mathrm{a} 2[\mathrm{]}$

$\mathrm{K} 1 \mathrm{a} 3[\mathrm{]}$

K1a4 [ ]

K1a5 [ ]

$\mathrm{K} 1 \mathrm{a} 6$ [ ]

1b [IF THE ANSWER TO QUESTION NO. 1 IS [2], ASK] if it happened because of [READ ALL. PLEASE

$1=$ Yes $0=$ No $66=$ TR MARK APPROPRIATE RESPONDENT'S ANSWER]

1. Don't have enough money to buy food

2. The type of food you want is not available

3. Not having enough time to buy or cook food

4. It's too difficult to reach the shop

5. On a diet

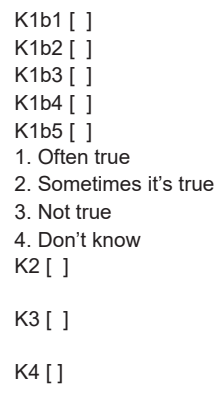

K4 []

Stage 1: Question 2-4

Now I will read to my mother some statements people have made about the food situation. For each statement please tell me whether the situation is true, sometimes true or not true with the condition of your mother's family during the past 12 months

"I'm worried that the food supply will run out before I have the money to buy more." In the past 12 months, was this statement often true, sometimes true, or not true for your family?

$3 \quad$ "The food that I bought has run out, and I don't have the money to buy any more." In the past 12 months, was this statement often true, sometimes true, or not true for your family?

$4 \quad$ "Mother cannot eat a balanced diet (rice with vegetables and side dishes) for the family." In the past 12
months, was this statement often true, sometimes true, or not true for your family?

Screening for stage 2: IF THERE IS A YES ANSWER to ONE of the questions 2-4 (eg "often true" or sometimes true") OR gives a response ${ }^{[3]}$ or ${ }^{[4]}$ to question 1, go to step 2; otherwise, stage 4 if there are children under the age of 18 in the family; if not, end the interview.

$5 \quad$ In the past 12 months, have you or other adults in your family reduced the amount of food you ate or did not eat because you didn't have enough money to buy food?

5 IF YES, How often does this happen - almost every month, in some month but not every month, or only in 1 or 2 months?
1. Yes

0. No (Skip 8a)

1. Almost every month

2. Several months, but not

every month

3. 1 or 2 months

88. ST/refuse

1. Yes

0 . No

88. ST/refuse

1. Yes

0 . No

88. ST/refuse

1. Yes

0 . No

88. ST/refuse
88. ST/reject (Skip 8a)

K5a [ to buy food?

Second level filtering (Filter to go to Stage 3)

Screening for stage 3: IF THERE IS A "YES" ANSWER to ONE of questions 5-8, go to step 3; otherwise, proceed to stage 4 if there are children under the age of 18 in the family; if not, end the interview.

9

In the past 12 months, have you or any other adults in your family missed a

1. Yes

0 . No

88. ST/refuse

1. Almost every month

2. Several months, but not

every month

3. 1 or 2 months

88. ST/refuse

IF YES, How often does this happen - almost
but not every month, or only in 1 or 2 months?
I will now read to you some of the statements that people have made about the food conditions associated with the children in your home. For each statement please tell me whether the situation is true, sometimes true or not true for your child/child living at your mother's house who is under 18 years old for the past 12 months.

"Mother only buys some kind of cheap food to feed the children because they often run out of money to buy food". In the past 12 months, was this statement often true, sometimes true, or not true for your family?

"Mother cannot feed her child with a balanced diet (consisting of rice, vegetable or animal side dishes, vegetables), because

11

12

she cannot afford it." In the past 12 months, was this statement often true, sometimes true, or not true for your family?

"Your child can't get enough to eat because you can't buy enough food." In the past 12 months, was this statement often true, sometimes true, or not true for your family?

13 In the past 12 months, did you reduce your child's portion because you did 1 . Yes

not have enough money to buy food?
K9 [ ]

K9a [

1. Often true

2. Sometimes it's true

3. Not true

4. Don't know

K10 [ ]

K11 [ ]

K12 [ ]

K13 [

88. ST/refuse 
Mahmudiono et al. Association between Household Food Security anemia

$14 \quad$ In the past 12 months, have your children ever missed meals (e.g. one meal a day) due to no money to buy food?

IF YES. How often does this happen - almost every month, a few months but not every month, or just 1 or 2 months?

1. Yes

88. ST/refuse

1. Almost every month

2. Several months but not

every month

3. 1 or 2 months

88. ST/refuse

1. Yes

0 . No

88. ST/refuse

1. Yes

0 . No

88. ST/refuse
K14 [ ]

K14a [ ]

K15 [

r.

